\title{
Inventarisasi Ekosistem Mangrove di Pesisir Randutatah, Kecamatan Paiton, Jawa Timur
}

\section{Mangrove Ecosystem Inventory in Randutatah Coastal, Paiton District, East Java}

Nurmujahidah Syamsuddina ${ }^{\mathrm{a}}$, Nyoto Santoso ${ }^{\mathrm{b}}$, Iis Diatin ${ }^{\mathrm{c}}$

a Program Studi Pengelolaan Sumberdaya Alam dan Lingkungan, Sekolah Pascasarjana, Institut Pertanian Bogor, Kampus IPB Dramaga, Bogor 16680

b Departemen Konservasi Sumberdaya Hutan dan Ekowisata, Fakultas Kehutanan, Institut Pertanian Bogor, Kampus IPB Dramaga, Bogor, 16680

c Departemen Budidaya Perikana, Fakultas Perikanan dan Ilmu Kelautan, Institut Pertanian Bogor, Kampus IPB Dramaga, Bogor, 16680

\section{Article Info:}

Received: 21 - 02 - 2019

Accepted: 15 - 05 - 2019

\section{Keywords:}

Diversity of fauna, mangrove ecosystem, plankton, Randutatah coastal.

\author{
Corresponding Author: \\ Nurmujahidah Syamsuddin \\ Program Studi Pengelolaan \\ Sumberdaya Alam dan \\ Lingkungan, Sekolah \\ Pascasarjana, Institut Pertanian \\ Bogor; \\ Tel. +62-82312692402, \\ Email: \\ nurmujahidahsy@gmail.com
}

\begin{abstract}
Mangrove ecosystem is a region that acts as a transition between land and sea. This ecosystem has ecological, socio-economic and physical functions. The decline in the quality and quantity of mangrove forests has resulted in very alarming impacts, such as increased abrasion, reduced fishing catches, seawater intrusion, and others. This study aims to analyze the biodiversity of mangrove ecosystem in the Randutatah coal. The results showed that mangrove ecosystems were dominated by Rhizophora stylosa species with the highest INP values in tillers and tree categories. Observations of fauna in the area found 2 types of mammals, 34 species of birds, 7 species of herpetofauna, and 9 species of insects. the wealth of bird species in this region is high. Phytoplankton composition is dominated by Bacillariophyceae class, zooplankton is dominated by crustacean class, and nekton is dominated by Mugilidae class. Mangrove conditions in Randutatah can increase biodiversity in these locations, as well as the condition of the waters around the mangrove ecosystem that become fertile so that it can be used by the community to catch fish or crabs that have an impact on the growth of the economic value of the community.
\end{abstract}

How to cite (CSE Style $8^{\text {th }}$ Edition):

Syamsuddin N, Santoso N, Diatin I. Inventarisasi ekosistem mangrove di Pesisir Randutatah, Kecamatan Paiton, Jawa Timur. JPSL 9(4): 893-903. http://dx.doi.org/10.29244/jps1.9.4.893-903.

\section{PENDAHULUAN}

Sebagian negara kepulauan, Indonesia terdiri atas 17504 buah pulau dengan panjang pantai sekitar 95 $181 \mathrm{~km}$ dengan kondisi biofisik lingkungan dan iklim yang beragam. Sebagian besar dari pantai tersebut ditumbuhi oleh hutan mangrove dengan lebar yang bervariasi dari mulai beberapa meter sampai beberapa kilometer dari garis pantai. Berdasarkan informasi terakhir, luas lahan yang bervegetasi mangrove di Indonesia dilaporkan sekitar 3.2 juta ha dan luas kawasan mangrove (termasuk lahan yang berpotensi ditanami mangrove) diduga sekitar 7.7 juta ha (Kusmana 2011).

Ekosistem mangrove memberikan manfaat secara ekologis sebagai penyedia nutrien, melindungi garis pantai dari erosi, menyediakan area pembibitan dan makan bagi banyak spesies ikan dan krustasea, intrusi air laut dan angin kencang, serta penahan tsunami. Mangrove juga memberikan manfaat ekonomis antara lain 
sebagai penyedia berbagai hasil hutan kayu, non kayu dan jasa ekosistem serta menyediakan tempat area pembibitan mangrove (Giri et al. 2010).

Salah satu faktor penting yang menyebabkan terjadinya perubahan pada wilayah pesisir adalah aktivitas pembangunan, seperti pemukiman, konversi lahan mangrove menjadi tambak dan industri. Kondisi tersebut membuat wilayah pesisir menjadi wilayah yang paling rentan terhadap perubahan, baik secara alami maupun fisik sehingga menyebabkan pengurangan luasan mangrove. Menurut Malik et al. (2015), pada tahun 19802003 setidaknya 1.1 juta ha mangrove hilang, 75\% dari daerah yang dikonversi ke budidaya tambak.

Ekosistem mangrove sebagai sumberdaya alam terbaharukan (renewable resources) pada beberapa daerah di Indonesia berada dalam posisi yang sangat menghawatirkan karena ekosistem tersebut terus mengalami penurunan kualitas dan kuantitas akibat degradasi. Menurut Kusmana (2011) ada tiga faktor utama penyebab kerusakan mangrove, yaitu (1) pencemaran, (2) konversi hutan mangrove yang kurang memperhatikan faktor lingkungan dan (3) penebangan yang berlebihan. Masalah yang terjadi di Desa Randutatah Kecamatan Paiton, Kabupaten Probolinggo, Provinsi Jawa Timur yaitu abrasi pantai sehingga luas daratan berkurang, serta pemanfaatan yang berlebihan (pengambilan ranting sebagai pakan ternak). Menurut Sinery (2015) banyak pengelolaan kawasan konservasi atau lindung yang tidak berhasil akibat perbedaan pemahaman konsep dasar konservasi/lindung yang sebenarnya mengakomodir keinginan masyarakat untuk mengelola sumberdaya alam dalam kawasan. Penelitian ini bertujuan untuk: (a) Menganalisis sebaran, kerapatan dan kondisi vegetasi mangrove, (b) Menganalisis fauna yang terdapat dalam ekosistem mangrove Desa Randutatah, (c) Menganalisis kelimpahan biota pada ekosistem mangrove Desa Randutatah.

\section{METODE}

\section{Lokasi dan Waktu Penelitian}

Penelitian dilaksanakan pada bulan Februari-Mei 2018 di kawasan hutan mangrove pesisir Randutatah, Kecamatan Paiton, Kabupaten Probolinggo, Jawa Timur. Secara astronomis, Desa Randutatah berada $7^{\circ} 43^{\prime} 00.9^{\prime \prime} \mathrm{LS}, 113^{\circ} 33^{\prime} 22.8^{\prime \prime} \mathrm{BT}$.

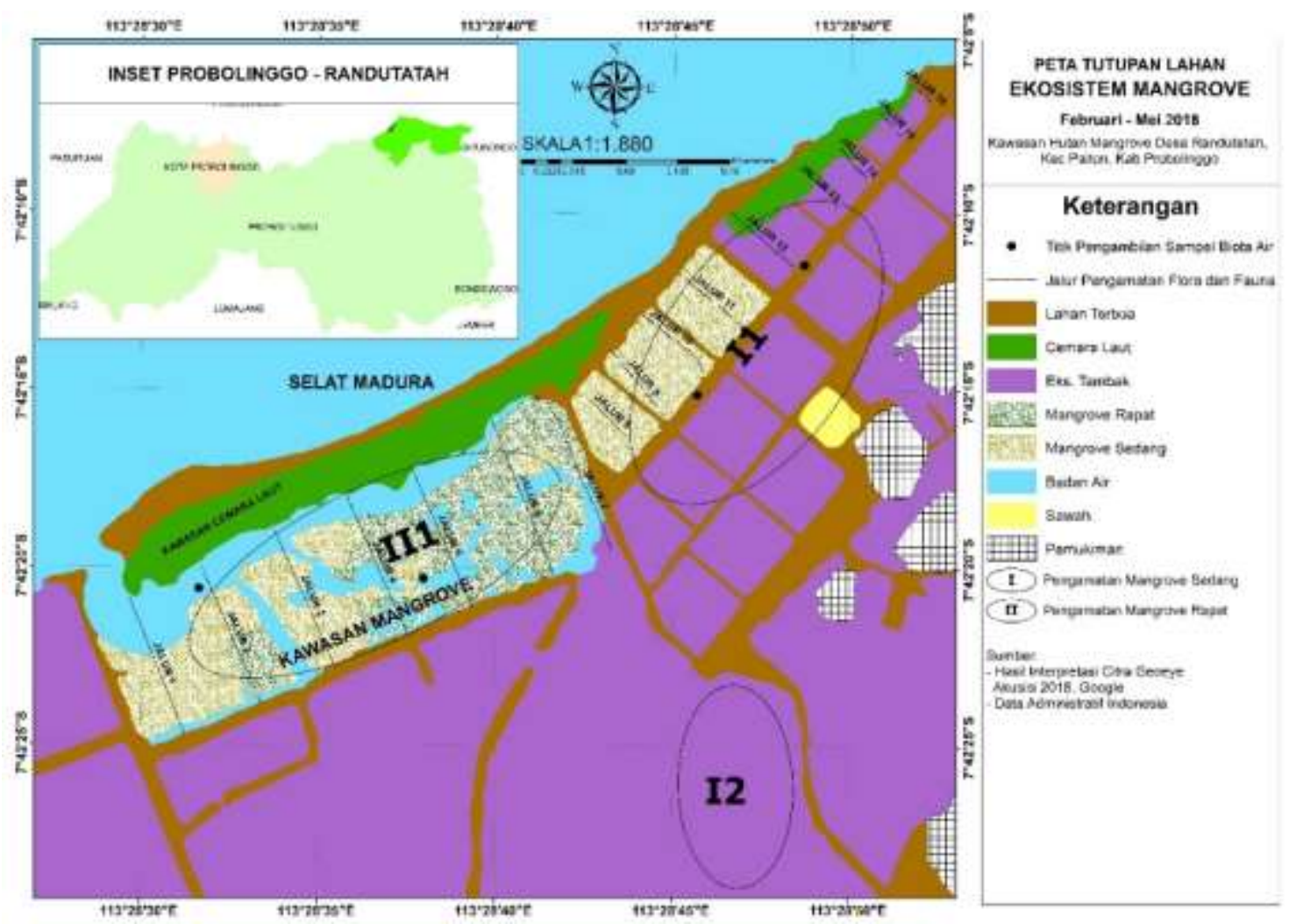

Gambar 1 Lokasi jalur pengamatan flora, fauna, biota air. 
Pengamatan flora dan fauna dibagi dalam dua jalur yaitu jalur barat dan timur. Jalur barat terdiri dari hutan mangrove kategori pohon yang rapat, sementara di jalur timur terdiri dari hutan mangrove kategori anakan. Sedangkan pengambilan sampel biota air dilakukan pada empat titik pengamatan. Peta jalur pengamatan mangrove disajikan pada Gambar 1.

\section{Metode Pengumpulan Data}

\section{Flora}

Pengambilan contoh untuk data vegetasi mangrove dikumpulkan dengan menggunakan metode kuadrat kombinasi jalur dan garis berpetak (Muller dan Ellenberg 1974; Kusmana 1997). Pada penelitian ini terdiri dari enam jalur transek tegak lurus garis pantai kearah darat. Setiap transek terdiri dari plot yang berukuran $10 \mathrm{x} 10 \mathrm{~m}^{2}$ untuk kategori pohon, $5 \times 5 \mathrm{~m}^{2}$ untuk kategori anakan, dan $2 \times 2 \mathrm{~m}^{2}$ untuk kategori semai. Sehingga total plot dalam penelitian berjumlah 18 plot.

\section{Fauna}

Pengambilan data dilakukan dengan 3 waktu pengamatan yaitu pagi, sore, dan malam. Hal ini didasari oleh perilaku satwa yang memiliki waktu aktif berbeda antara jenis satu dengan yang lain. Satwa liar yang diamati pada pagi dan sore hari yaitu burung dan serangga, sedangkan pada malam hari satwa liar yang diamati yaitu herpetofauna dan mamalia.

\section{- Mamalia}

Pengambilan data mamalia menggunakan metode rapid assesment yaitu pengamatan cepat dengan mencatat jenis-jenis mamalia yang ditemukan dan tidak harus dilakukan pada suatu jalur khusus atau lokasi khusus. Pengamat mencatat baik perjumpaan secara langsung maupun tidak langsung yang diketahui keberadaannya melalui jejak (jejak kaki, kotoran, rontokan rambut, dan bekas atau sisa makanannya).

\section{- Burung}

Pengambilan data burung menggunakan metode titik hitung (Point count) (Bibby et al. 2000). Pengamatan dilakukan dengan berdiri pada titik tertentu pada habitat yang diteliti kemudian mencatat perjumpaan terhadap burung dalam rentang waktu tertentu (Van Helvoort 1981). Dalam penelitian ini jarak antar titik ditetapkan $100 \mathrm{~m}$ dengan radius pengamatan $50 \mathrm{~m}$. Panjang jalur di setiap habitat adalah $1000 \mathrm{~m}$ dengan pengamatan pada setiap titik dilakukan selama 10 menit. Pengamatan dilakukan pada pagi dan sore hari. Parameter yang diukur adalah jenis, jumlah individu dan waktu perjumpaan.

Selain penggunaan metode point count, digunakan pula metode daftar jenis MacKinnon. Metode ini dilakukan dengan mencatat 10 - 20 jenis burung yang baru dilihat pada tiap daftar di area pengamatan.

\section{- Herpetofauna}

Metode yang digunakan dalam inventarisasi herpetofauna adalah Visual Encounter Survey (VES) (Heyer et al. 1994). Metode ini umumnya digunakan untuk menentukan kekayaan jenis suatu daerah, untuk menyusu daftar jenis, serta untuk memperkirakan kelimpahan relatif jenis satwa yang ditemukan. Metode ini biasa dilakukan di sepanjang jalur, pada suatu plot, sepanjang sisi sungai, sekitar tepi kolam dan seterusnya selama reptil dan amfibi dapat terlihat.

- Serangga

Pengamatan serangga dilakukan dengan cara Direct Sweeping yaitu menangkap langsung seranggaserangga dengan bantuan jaring. Metode pengamatan yang dilakukan mencakup metode transek baik mengikuti jalur maupun transek garis. 


\section{Biota Air}

- Plankton

Pengambilan data plankton dilakukan di empat titik. Pengambilan data plankton menggunakan plankton net dan ember volume $5 \mathrm{~L}$. Pengambilan contoh plankton dilakukan dengan cara mengambil 100 liter air dari permukaan perairan kemudian disaring dengan plankton net. Selanjutnya, air contoh disimpan dalam botol polyetilen ukuran $250 \mathrm{~mL}$ dan diawetkan dengan larutan Lugol $1 \%$ untuk kemudian dianalisis di laboratorium (Meidwilestari 2017).

- Nekton

Pengambilan data nekton dilakukan di empat lokasi disekitar muara sungai Pantai Duta, Desa Randutatah. Pengambilan data nekton menggunakan jala lempar dengan ukuran mesh zise 2-3 cm.

\section{Metode Analisis Data}

\section{Flora}

Sesuai dengan kondisi lingkungannya, flora disuatu tempat dapat terdiri dari beragam jenis yang masingmasing dapat terdiri dari beragam variasi gen yang hidup dibeberapa tipe habitat, oleh karena itu muncul istilah keanekaragaman flora yang mencakup makna keanekaragaman jenis, keanekaragaman genetik dari jenis, dan keanekaragaman habitat dimana jenis-jenis flora tersebut tumbuh (Kusmana dan Hikmat, 2015).

Parameter yang menjadi fokus pengamatan adalah kerapatan jenis, frekuensi jenis, luas area penutupan, dan nilai penting jenis suatu spesies serta keanekaragaman spesies yang menggunakan perhitungan seperti berikut ini.

- Kerapatan $(\mathrm{K}) \quad$ : Jumlah individu/Luas area sampling

- Kerapatan Relatif $(\mathrm{Kr}) \quad$ : (Kerapatan suatu jenis/total kerapatan selurh jenis)x100\%

- Frekuensi (F) : (Jumlah plot ditemukannya suatu jenis/jumlah seluruh plot)

- Frekuensi Relatif (Fr) : (Frekuensi suatu jenis/frekuensi seluruh jenis)x100\%

- Dominansi (D) : (Jumlah basal area suatu jenis/luas area sampling)x100\%

- Dominansi Relatif(DR) : (Dominansi suatu jenis/dominansi seluruh jenis)x100\%

- Indeks Nilai Penting (INP) pancang, tiang, dan pohon $=\mathrm{KR}+\mathrm{FR}+\mathrm{DR}$

- $\quad$ INP Semai $=$ KR + FR

- Keanekaragaman (Diversity) Indeks Shannon Wienner (1949) dalam Barbour et al. (1987) $H^{\prime}=-\sum_{i=1}^{s}(P i)(\ln P i)$

\section{Fauna}

Analisis data mamalia, herpetofauna, dan serangga yang dilakukan sebatas pencatatan jumlah pertemuan dengan satwa berdasarkan metode pengamatan yang telah dijelaskan sebelumnya.

- Burung

Perolehan pengumpulan data burung di lapangan dianalisis dan diklasifikasi dengan metode sebagai berikut:

Dominansi : Jumlah individu suatu jenis/Jumlah inividu seluruh jenis 
Keterangan:

$$
\mathrm{H}^{\prime} \quad \text { : }-\sum \text { pi } \ln \text { pi }
$$

$\mathrm{H}^{\prime} \quad$ : Indeks keanekaragaman jenis

$\mathrm{Pi} \quad$ : Proporsi nilai penting (jumlah perjumpaan jenis i/jumlah perjumpaan seluruh jenis)

Ln : logaritma natural

\section{Biota Air}

- Plankton

Plankton dibagi kedalam dua jenis, yaitu fitoplankton dan zooplankton. Analisis plankton dilakukan untuk mendapatkan nilai kelimpahan dan jumlah jenis. Analisis dilakukan dengan pencacahan plankton menggunakan mikroskop majemuk dan dihitung dengan bantuan Sedgewick Rafter Counting Chamber (SRC) (Volume1 mL). Analisis fitoplankton dilakukan dengan menggunakan teknik strip, sedangkan analisis zooplankton menggunakan teknik sensus.

- Nekton

Hasil tangkapan jala lempar dimasukan kedalam plastik ziplock kemudian diawetkan dalam formalin dengan konsentrasi 10\% dan diidentifikasi jenisnya dengan menggunakan buku "The Living Marine Resources of the Western Central Pacific" dari FAO.

\section{HASIL DAN PEMBAHASAN}

\section{Distribusi dan Kerapatan Jenis Mangrove}

Secara umum, dari hasil pengamatan pada seluruh wilayah di kawasan Randutatah jenis mangrove relatif homogen. Distribusi jenis mangrove yang banyak ditemukan adalah jenis Rhizophora stylosa sehingga dapat dikatakan bahwa jenis ini mendominasi di kawasan Randutatah. Jenis lain juga ditemukan di kawasan ini yaitu Sonneratia alba, Rhizophora mucronata, dan Avicennia marina. Secara terperinci, pada transek 1 ditemukan jenis Rhizophora mucronata dan Rhizophora stylosa, transek 2, 4, 5, dan 6 ditemukan seluruh jenis yaitu Sonneratia alba, Rhizophora mucronata, Avicennia marina, dan Rhizophora stylosa, transek 3 hanya Avicennia marina yang tidak ditemukan, sedangkan petakan 3, 4, 5, dan 6 hanya ditemukan Rhizophora stylosa.

Berdasarkan hasil pengamatan, kondisi mangrove di kawasan ini sangat rapat, hal ini dibuktikan dari hasil analisa bahwa kerapatan mangrove kategori pohon adalah 1.150- 3.120 ind/ha untuk kategori anakan adalah 10.800-30.400 ind/ha, dan semai adalah 70.000-170.000 ind/ha (Tabel 1).

Pengamatan kerapatan mangrove pada kategori anakan maupun semai dilakukan untuk mengetahui tingkat regenerisasi yang dimungkinkan terjadi di kawasan ini. Berdasarkan hasil pengamatan dan analisa data menunjukkan bahwa kawasan ini memiliki penerus yang berjumlah cukup banyak dalam satuan hektar, meskipun tidak dilakukan penanaman maupun tambal sulam. Hal ini dapat dilakukan dengan asumsi tidak adanya hama atau aktivitas yang merusak mangrove.

Tabel 1 Kerapatan mangrove di kawasan Randutatah jalur barat.

\begin{tabular}{ccccccc}
\hline \multirow{2}{*}{ Kategori Jumlah Tegakan (ind./ha) } \\
\cline { 2 - 7 } & Transek 1 & Transek 2 & Transek 3 & Transek 4 & Transek 5 & Transek 6 \\
\hline Pohon & 3120 & 1933.33 & 1633.33 & 1600 & 1150 & 1600 \\
& (Baik/Sangat & (Baik/Sangat & (Baik/Sangat & (Baik/Sangat & (Baik/ & (Baik/Sangat \\
Anakan & Baik) & padat) & padat) & Padat) & Sedang) & Padat) \\
Semai & 18400 & 23200 & 26533.33 & 23866.67 & 19000 & 30400 \\
\hline
\end{tabular}


Tabel 2 Kerapatan mangrove di kawasan Randutatah jalur timur.

\begin{tabular}{ccccc}
\hline \multirow{2}{*}{ Kategori } & \multicolumn{4}{c}{ Jumlah Tegakan (ind./ha) } \\
\cline { 2 - 5 } & Plot 3 & Plot 4 & Plot 5 & Plot 6 \\
\hline Pohon $*$ ) & - & - & - & - \\
Anakan & 11600 & 10800 & 10800 & 13600 \\
Semai & 70000 & 170000 & 110000 & 110000 \\
\hline
\end{tabular}

Jumlah kerapatan mangrove tertinggi kategori pohon adalah pada transek 1 (3 $120 \mathrm{ind} / \mathrm{ha}$ ) dan terendah pada transek 5 (1 $150 \mathrm{ind} / \mathrm{ha}$ ). Sedangkan jumlah kerapatan tertinggi kategori anakan adalah pada transek 6 (30 $400 \mathrm{ind} / \mathrm{ha}$ ), terendah pada plot 4, 5 (10 $800 \mathrm{ind} / \mathrm{ha}$ ). Dan untuk mangrove kategori semai kerapatan tertinggi adalah plot 4 (170 $000 \mathrm{ind} / \mathrm{ha}$ ) dan terendah plot 3 (70 $000 \mathrm{ind} / \mathrm{ha}$ ). Berdasarkan Keputusan Menteri Negara Lingkungan Hidup Nomor 201 Tahun 2004 menunjukkan bahwa mangrove pada transek 1, 2, 3, 4, dan 6 masuk kategori baik dengan kerapatan sangat padat, sedangkan transek 5 termasuk kategori baik dengan kerapatan sedang. Tingginya kerapatan mangrove pada transek 1 disebakan oleh waktu penanaman, dimana penanaman mangrove pada transek 1 dilaksanakan pada tahun 1998.

\section{Indeks Nilai Penting, Indeks Keanekaragaman, Indeks Kemerataan, dan Indeks Dominansi}

INP mangrove kategori pohon tertinggi adalah Rhizophora stylosa yang terdapat pada seluruh transek. INP Mangrove kategori pohon disajikan pada Gambar 1. Pada keseluruhan transek nilai INP tertinggi pada kategori pohon adalah Rhizophora stylosa (212.92), selanjutnya INP tertinggi kedua adalah Sonneratia alba (148.43), Rhizophora mucronata (139.99), dan yang terakhir adalah Avicennia marina (63.65). Untuk kategori anakan INP tertinggi adalah Rhizophora stylosa. INP kategori anakan disajikan pada Gambar 2. Sama seperti kategori pohon, nilai INP tertinggi adalah jenis Rhizophora stylosa ( 224.13), kemudian Rhizophora mucronata (133,93), Avicennia marina (68.86), dan yang terendah adalah Sonneratia alba (37.04). Nilai indeks keanekaragaman mangrove, kemerataan, dan dominansi disajikan pada Tabel 3.

Nilai keanekaragaman jenis ( $\mathrm{H}^{\prime}$ ) di kawasan Randutatah tertinggi dimiliki oleh transek 6 yaitu 1,948 dan terendah pada transek 2 yaitu 1,071. Berdasarkan kriteria keanekaragaman Barbour et al. (1987); H'=1-2 (rendah), $\mathrm{H}^{\prime}=2-3$ (sedang), $\mathrm{H}^{\prime}=3-4$ (tinggi), $\mathrm{H}^{\prime}=>4$ (sangat tinggi), maka dapat diketahui bahwa indeks keanekaragam jenis mangrove secara umum di kawasan tersebut tergolong rendah. Nilai kemerataan tertinggi dimiliki oleh transek 6 yaitu 0,383 sedangkan terendah adalah transek $1(0,113)$, mengacu pada kriteria kemerataan Brower et al. (1997); $\mathrm{E}<0.4$ (rendah), $0.4 \leq \mathrm{E}<0.6$ (sedang), $\mathrm{E} \geq 0.6$ (tinggi), maka kategori indeks kemerataan jenis mangrove dalam komunitas tumbuhan di kawasan penelitian tergolong rendah. Nilai dominansi tertinggi dimiliki oleh transek 1 yaitu 0,619 dan masuk kategori tinggi ( $0.6-\leq 1)$, sedangkan nilai terendah dimiliki transek 6 yaitu 0.279 dengan kategori rendah $(0-\leq 0.3)$. Nilai indeks keanekaragaman, dan kemerataan tergolong rendah karena adanya dominansi dari salah satu jenis mangrove yang ditanam, hal ini disebabkan oleh masih rendahnya pengetahuan masyarakat tentang jenis-jenis mangrove yang dapat ditanam selain itu juga disebabkan oleh ketersediaan bibit sewaktu penanaman.

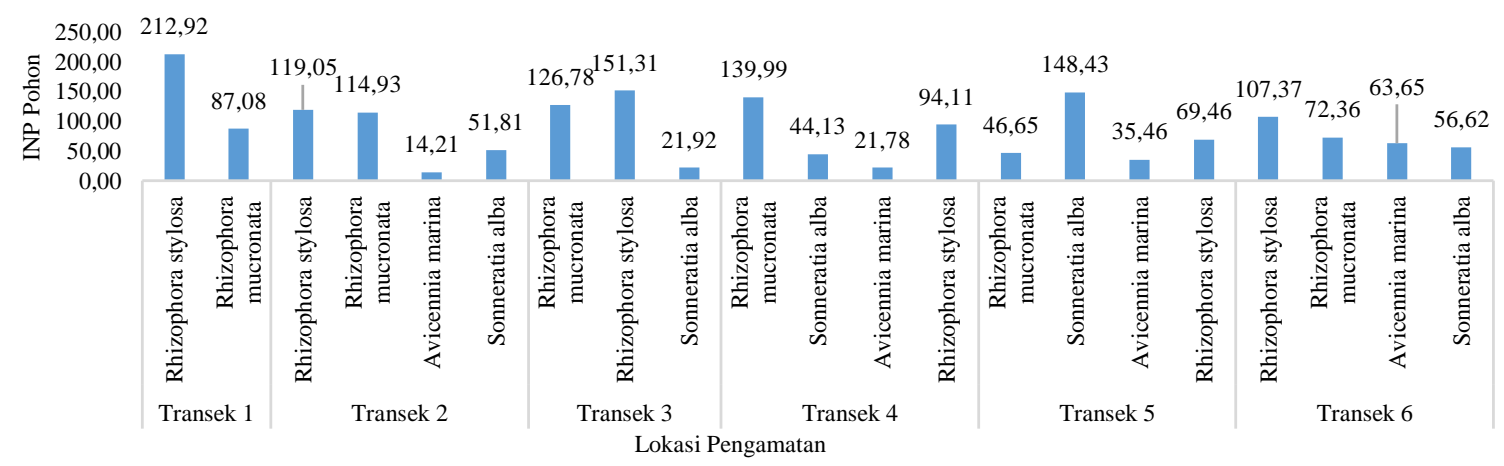

Gambar 1 INP mangrove kategori pohon. 


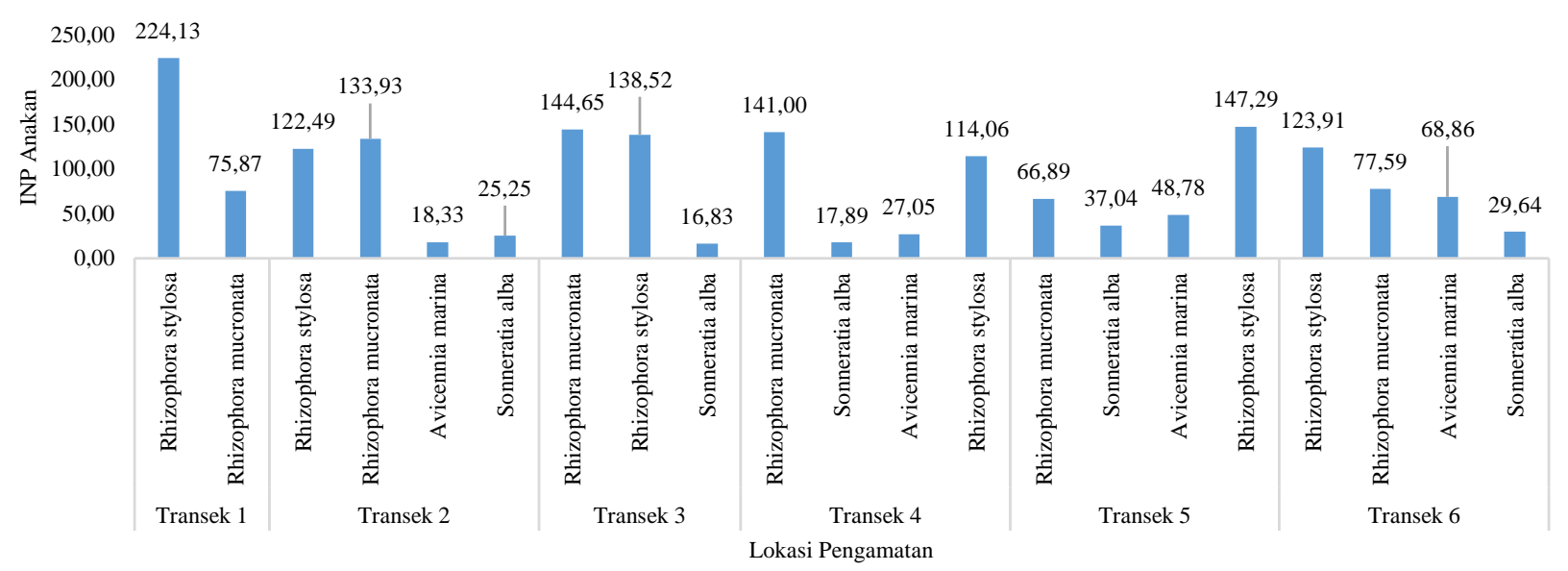

Gambar 2 INP mangrove kategori anakan.

Tabel 3 Indeks keanekaragaman (H'), kemerataan populasi (E), dan Dominansi (D) ekosistem mangrove.

\begin{tabular}{ccccccc}
\hline Transek & $\mathrm{H}^{\prime}$ & Kategori & E & Kategori & D & Kategori \\
\hline 1 & 1,540 & Rendah $\left(H^{\prime}=1-2\right)$ & 0,113 & Rendah $(\leq 0,4)$ & 0,619 & Tinggi $(0,6-\leq 1)$ \\
2 & 1,071 & Rendah $\left(H^{\prime}=1-2\right)$ & 0,259 & Rendah $(\leq 0,4)$ & 0,386 & Sedang $(0,3-\leq 0,6)$ \\
3 & 1,824 & Rendah $\left(H^{\prime}=1-2\right)$ & 0,212 & Rendah $(\leq 0,4)$ & 0,472 & Sedang $(0,3-\leq 0,6)$ \\
4 & 1,605 & Rendah $\left(H^{\prime}=1-2\right)$ & 0,285 & Rendah $(\leq 0,4)$ & 0,378 & Sedang $(0,3-\leq 0,6)$ \\
5 & 1,543 & Rendah $\left(H^{\prime}=1-2\right)$ & 0,365 & Rendah $(\leq 0,4)$ & 0,388 & Sedang $(0,3-\leq 0,6)$ \\
6 & 1,948 & Rendah $\left(H^{\prime}=1-2\right)$ & 0,383 & Rendah $(\leq 0,4)$ & 0,279 & Rendah $(0-\leq 0,3)$ \\
\hline
\end{tabular}

\section{Komunitas Fauna}

\section{Spesies fauna yang dijumpai}

Hasil pengamatan fauna di kawasan Randutatah ditemukan sebanyak 2 jenis mamalia dari 2 famili, 34 jenis burung dari 18 famili, 7 jenis herpetofauna (5 jenis reptil dari 5 famili, 2 jenis amphibi dari 2 famili), dan 9 jenis insecta/serangga dari 9 famili. Fauna yang ditemukan tersebar di area kawasan mangrove Randutatah, secara diagram ditampilkan pada Gambar 4 berikut.

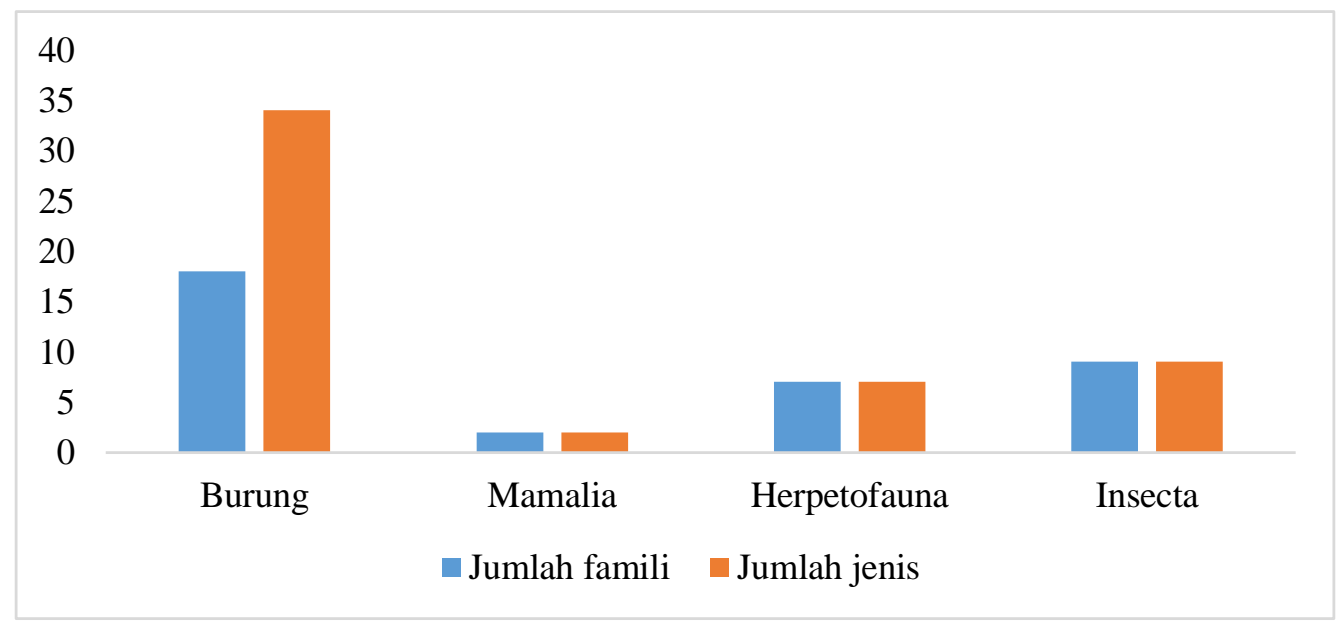

Gambar 4 Keanekaragaman fauna yang ditemukan di kawasan Randutatah.

Hasil pengamatan menunjukkan bahwa ditemukan dua jenis mamalia dari famili yang berbeda yaitu jenis Garangan Jawa (4 ekor) dari famili Herpestidae, dan codot kawar (11 ekor) dari famili Pteropodidae. Untuk burung yang ditemukan berasal dari famili Ardeidae (155 ekor), famili Accipitridae ( 2 ekor), famili falcaonidae (1 ekor), famili Phasianidae (1 ekor), famili Charadriidae (16 ekor), famili Scolopacidae(6 ekor) famili 
Columbidae (33 ekor), famili Caprimulgidae (12 ekor), famili Apodidae(110 ekor), famili Alcedinidae (62 ekor), famili Pycnonotidae (25 ekor), famili Sylviidae (39 ekor), famili Rhipiduridae (33 ekor), famili Pachycephalidae (4 ekor), famili Nectariniidae (5 ekor), famili Dicaeidae (1 ekor), famili Zosteropidae (2 ekor), dan famili Ploceidae (94 ekor). 34 jenis burung yang ditemukan ini berasal dari 18 famili dengan total 600 individu burung. Selain itu juga terdapat 7 jenis burung yang dominan, 9 jenis keberadaannya subdominan dan sisanya sekitar 18 jenis burung tidak dominan keberadaannya

Herpetofauna ditemukan 9 jenis famili yaitu Colubridae (1 ekor), Varanidae (1 ekor), Homalopsidae (1 ekor), Scincidae (4 ekor), Gekkonidae (9 ekor), Ranidae (5 ekor), Dicroglossidae (13 ekor). Serangga ditemukan 9 famili yaitu Vespidae (14 ekor), Orthoptera (1 ekor), Crididae (1 ekor), Acrididae (3 ekor), Lycaenidae (4 ekor), Myrmeleontidae (4 ekor), Neopetaliidae (1 ekor), Noctuidae(1 ekor), Libellulidae (2 ekor).

Keberadaan ekosistem mangrove memberikan peranan yang penting bagi keberadaan jenis satwa tersebut. Hal ini dikarenakan kawasan mangrove dijadikan tempat berbiak, tempat mencari pakan dan menjadi tempat beristirahat untuk satwa yang berada di kawasan mangrove dan sekitarnya.

\section{Keanekaragaman Jenis dan Kemerataan Jenis Satwa}

Pengukuran indeks dilakukan hanya pada taksa burung. Hal ini dikarenakan pada taksa mamalia, herpetofauna, dan juga serangga memiliki keanekaragaman yang sedikit sehingga tidak diperlukan pengukuran untuk indeksnya. Pada Gambar 4 ditampilkan nilai sebaran indeks pada fauna yang ditemukan di kawasaan Randutatah.

Pada ketiga indeks tersebut terlihat bahwa temuan fauna di lapangan menunjukkan keanekaragaman Shannon - Wiener (H') 2.9 yang berarti keanekaragaman sedang. Kemudian hasil perhitungan kemerataan Eveness (E) menunjukkan angka 0.85 yang berarti komunitas di kawasan ini sudah stabil. Indeks kekayaan margalef juga menunjukkan nilai positif dengan nilai indeks Dmg 5 yang mengartikan kekayaan jenis burung di kawasan ini tergolong tinggi.

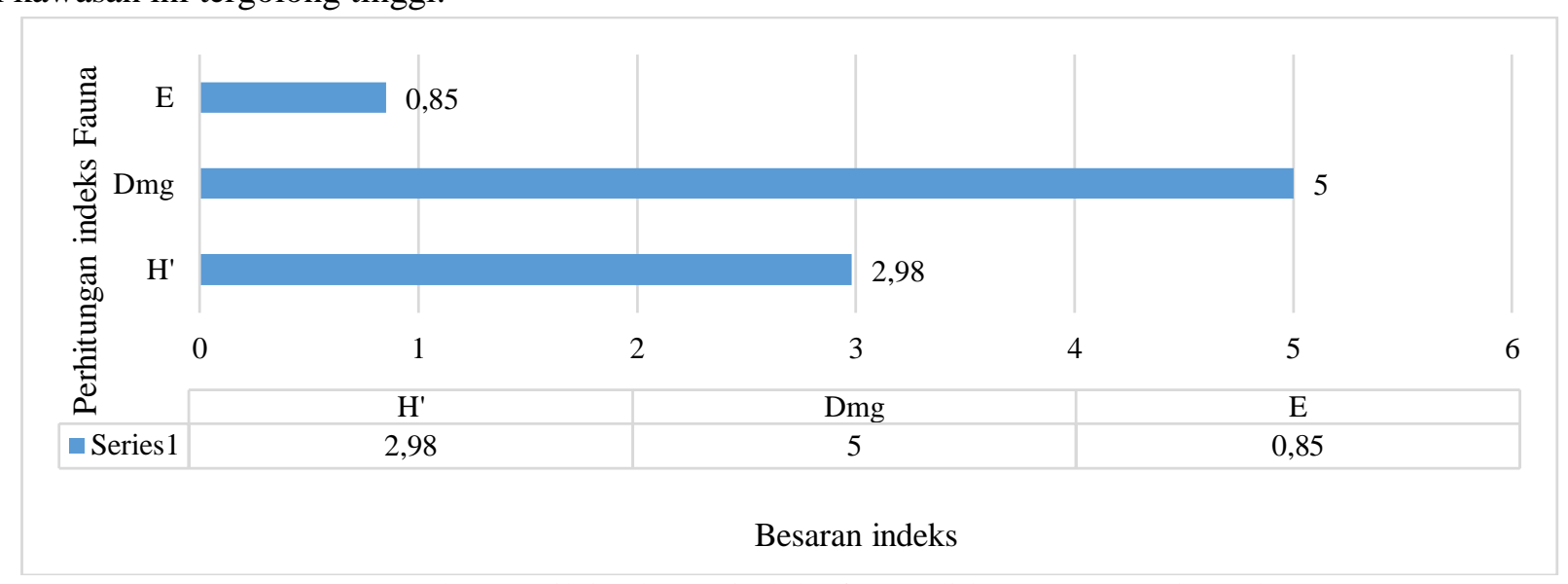

Gambar 5 Nilai sebaran indeks fauna di kawasan Randutatah.

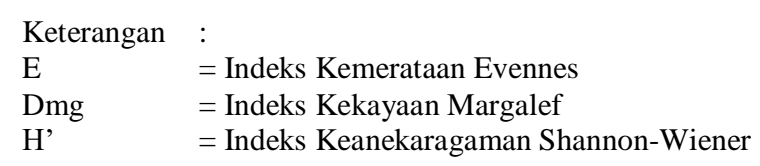

Pengamatan dengan menggunakan metode MacKinnon didapatkan sebanyak 10 daftar jenis burung dengan penemuan 34 jenis burung. Daftar jenis burung tersebut kemudian disajikan dalam bentuk kurva penemuan jenis burung yang menunjukkan hubungan kenaikan jenis burung yang ditemukan dari tiap daftar jenis yang didapatkan (Gambar 6). 
Menurut MacKinnon et al. (2011) kecuraman pada kurva menunjukkan kekayaan jenis burung dan menentukan masih adanya penemuan jenis baru yang belum tercatat. Kurva penemuan jenis di kawasan mangrove Randutatah memiliki kecuraman hingga akhir daftar jenis. Hal ini menunjukkan bahwa masih ada kemungkinan penambahan jenis baru pada kawasan tersebut.

Keberadaan kawasan Randutatah termasuk sangat penting untuk konservasi keanekaragaman hayati di area desa Randutatah. Angka-angka tersebut menunjukkan hal yang positif dan membuktikan bahwasanya kawasan konservasi ini perlu dipertahankan keberadaannya. Kegiatan pembinaan habitat yang dilakukan juga akan menambah stabil dan memperbaiki komunitas fauna yang ada di kawasan konservasi ini.

\section{Status keterancaman}

Status keterancaman pada satwa yang berada di ekosistem mangrove Randutatah sebagian besar memiliki status LC yang artinya satwa pada kawasan ini memiliki tingkat keterancaman yang masih tergolong rendah terhadap kepunahan, hanya ada satu jenis satwa yang statusnya VU yaitu Puyuh gonggong biasa yang artinya jenis ini sudah dinyatakan rentan terhadap kepunahan. Terdapat pula jenis satwa yang dilindungi yaitu sebanyak 12 jenis satwa yang statusnya dili dungi oleh pemerintah yaitu Blekok sawah, Kowak malam merah, Kuntul besar, Kuntul karang, Kuntul kecil, Kuntul kerbau, Elang laut perut putih, Alap-alap sapi, Cekakak suci, Cekakak sungai, Raja udang biru, Burungmadu sriganti, dan terdapat 2 jenis satwa yang memiliki status Appendix II CITES yang artinya jenis tersebut populasinya genting mendekati terancam punah sehingga kontrol perdagangannya secara ketat dan diatur dengan aturan yang ketat yaitu Elang laut perut putih, Alapalap sapi.

\section{Biota Air}

\section{- Plankton}

Komposisi fitoplankton di perairan Randutatah selama pengamatan terbagai menjadi tiga kelas yaitu kelas Bacillariophyceae, kelas Dynophyceae, dan kelas Cyanophyceae.

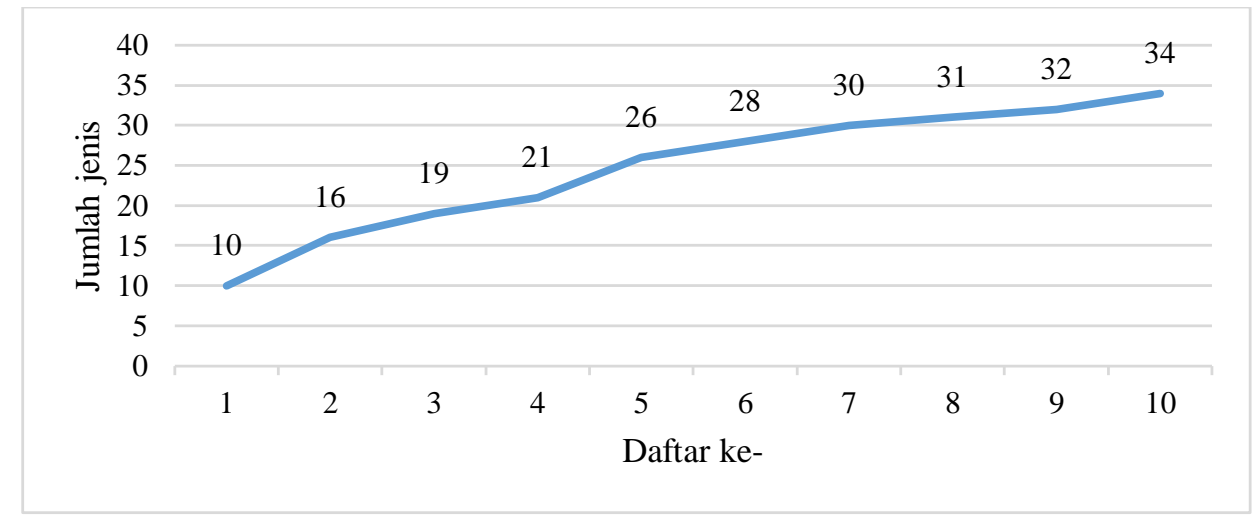

Gambar 6 Kurva kenaikan perjumpaan burung.

Tabel 4 Kelimpahan plankton di perairan Randutatah.

\begin{tabular}{ccccc}
\hline \multirow{2}{*}{ Jenis } & \multicolumn{3}{c}{ Kelimpahan $\left(\mathrm{sel} / \mathrm{m}^{3}\right)$} \\
\cline { 2 - 5 } & St.1 & St.2 & St.3 & St.4 \\
\hline Fitoplankton & 214677 & 290546 & 1150000 & 1895934 \\
Zooplankton & 49574 & 108632 & 1212682 & 387208 \\
\hline
\end{tabular}


Pada stasiun pengamatan yang mendominasi kelas Bacillariophyceae. Kelas Bacillariophyceae memiliki tingkat toleransi dan adaptasi yang baik terhadap perubahan lingkungan. Kondisi perairan yang didominasi oleh Bacillariophyceae atau dikenal sebagai diatom dalam kuantitas yang banyak menunjukkan tahap kualitas air yang bersih (Muhammad Ali et al. 2003).

Untuk zooplankton didominasi oleh kelas Crustacea sebesar 43.92\%, kelas Ciliata sebesar $40.93 \%$, kelas Bivalvia 7.57\%, kelas gastropoda 7.51\%, dan kelas Polychaeta 0.03\%. Menurut Arinardi et al. (1997) bahwa dominasi Crustacea pada perairan berkaitan dengan sifat omnivora atau pemakan segala (Fitoplankton, Zooplankton, Detritus), sehingga mudah untuk mendapat makanan.

\section{- Nekton}

Selama pengamatan ikan di sekitar kawasan konservasi, keluarga Mugilidae merupakan jenis yang banyak dijumpai. Pada Tabel 5 menunjukkan dari tujuh jenis ikan yang ditemukan di lokasi penelitian, terdapat 6 jenis ikan yang memiliki resiko rendah (LC) dan 1 jenis ikan yang terancam punah (NT) menurut status konservasi IUCN. Dari 2 jenis yang memiliki resiko rendah tersebut berasal dari family yang sama yaitu mugilidae. Klasifikasi jenis ikan di perairan Randutatah disajikan pada Tabel 5.

Tabel 5 Klasifikasi jenis ikan di perairan Randutatah

\begin{tabular}{ccclcc}
\hline & \multicolumn{2}{c}{ Nama Jenis } & \multicolumn{3}{c}{ Status Konservasi } \\
\cline { 2 - 5 } Famili & Ilmiah & Lokal & IUCN & CITES & PP no. 7 Thn 1999 \\
\hline Terapontidae & Terapon jarbua & Kerong-kerong & LC & - & - \\
Cichlidae & Oreochromis mossambicus & Mujair & NT & - & - \\
Gobidae & Periophthalmus sp. & Gelodok & LC & - & - \\
Bagridae & Hemibagrus sp. & Baung & LC & - & - \\
Mugilidae & Chelon subviridis & Belanak & LC & - & - \\
Mugilidae & Moolgarda engeli & Belanak & LC & - & - \\
Lutjanidae & Lutjanus sp. & Kakap & LC & - & - \\
\hline
\end{tabular}

Pada umumnya dari keluarga Gobidae (Gelodok), Mugilidae (Belanak), Terapontidae (Kerong-kerong), dan Bagridae (Baung) merupakan jenis ikan yang cenderung di jumpai di perairan estuari. Untuk jenis Cichlidae (Mujair) pada umumnya merupakan ikan air tawar, namun mampu beradaptasi terhadap salinitas. Sedangkan untuk jenis Lutjanidae (Kakap) merupakan ikan laut yang menempati habitat terumbuh karang. Beberapa ikan laut baik yang hidup di terumbu karang biasanya menjadikan daerah estuari terutama daerah mangrove sebagai daerah pemijahan, karena ekosistem mangrove merupakan ekosistem yang subur dan sesuai untuk stadia awal hidup ikan.

\section{SIMPULAN}

Kondisi ekosistem mangrove desa Randutatah masuk dalam kategori baik, hal ini terlihat dari nilai kerapatan mangrove yang tergolong tinggi (1 150-3 120 ind/ha) selain itu diperkirakan juga kondisi mangrove Randutatah masih dalam kategori kerapatan pohon tinggi untuk 5-10 tahun kedepan dengan melihat tingginya nilai kerapatan mangrove kategori anakan dan semai (10 800 - $30400 \mathrm{ind} / \mathrm{ha}$ dan 70000 - $170000 \mathrm{ind} / \mathrm{ha})$. Kondisi mangrove yang memilki kerapatan tinggi berkorelasi positif terhadap jumlah fauna yang ditemukan selama pengamatan, terutama burung yang memiliki indeks kekayaan tinggi. Kondisi mangrove yang baik dapat meningkatkan keanekaragaman biodiversity di lokasi tersebut, begitupun dengan kondisi perairan disekitar ekosistem mangrove yang menjadi subur sehingga dapat dimanfaatkan oleh masyarakat untuk menangkap ikan atau kepiting yang berdampak pada pertumbuhan nilai ekonomi masyarakat.

\section{UCAPAN TERIMA KASIH}

Terima kasih penulis ucapkan kepada Dinas Lingkungan Hidup Kabupaten Probolinggo, dan masyarakat desa Randutatah atas dukungan data-data terkait mangrove Randutatah yang diperlukan dalam penelitian ini. 


\section{DAFTAR PUSTAKA}

[CITES] Convention on International Trade in Endangered Species of Wild Flora and Fauna. 2009. CITES. Appendices I, II, dan III [Internet]. [diunduh 2018 Jan 15]. Tersedia pada https://www.cites.org.

Arinardi OH, Sutomo AB, Yusuf SA, Trimaningsih E A, Riyono SH. 1997. Kisaran kelimpahan dan komposisi plankton predominan di Perairan Kawasan Timur Indonesia. Jakarta: P3O-LIPI.

Barbour MG, Burk JH, Pitts WD. 1987. Terrestrial Plant Ecology. Second Edition. California: The Benjamin/Comings Publishing Company.

Bibby C, Jones M, Marsden S. 2000. Teknik-Teknik Lapangan Survei Burung. Bogor: Birdlife Indonesia Programme.

Brower JE, Zar JH, Ende CNV. 1980. Field and Laboratory Methods for General Ecology. Dubuque: Wm. C. Brown Publisher.

Giri C, Pengra B, Zhu Z, Singh A, Tieszen LL. 2010. Monitoring mangrove forest dynamics of the Sundarbans in Bangladesh and India using multi-temporal satellite data from 1973 to 2000. Estuarin Coastal and Shelf Science. 73: 91-100.

Heyer WR, Donnelly MA, McDiarmid RV, Hayek LA \& Foster MS.(eds). 1994. Measuring and Monitoring Biological Diversity. Standar Methods for Amphibians. Washington DC: Smithsonian Institution Press.

Kusmana C, Hikmat A. 2015. Keanekaragaman Hayati Flora di Indonesia. Jurnal Pengelolaan Sumberdaya Alam dan Lingkungan. 5(2): 187-198.

Kusmana C. 2011. Management Of Mangrove Ecosystem In Indonesia. Jurnal Pengelolaan Sumberdaya Alam dan Lingkungan. 2(1): 152-157.

MacKinnon J, Phillipps K, vanBalen B. 2011. Burung-Burung di Sumatera, Jawa, Bali dan Kalimantan. Bogor: Burung Indonesia.

Malik A, Fensholt R, Mente O. 2015. Economic Valuation of Mangroves for Comparison with Commercial Aquaculture in South Sulawesi, Indonesia. Forests. (6): 3028-3044.

Muhamma Ali, Vadus S, Saima J, Tasveer Z. 2003. Studies on Biodiversity in Relation to Seasonal Variation in Water of River Indus at Ghazi GAT, Punjab, Pakistan. Pakistan Journal of Biological Sciences. 6 (21): 1840-1844.

Van Helvoort B. 1981. Study of Bird Population in The Rural Ecosystem of West Java, Indonesia a Semi Quantitative Approach. Nature Conservation Dept. The Netherlands: Agriculture University Wageningham. 